\title{
Driver-passenger communicative stress and psychological distress among Chinese bus drivers: the mediating effect of job burnout
}

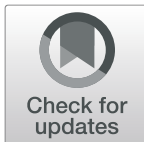

Zhihao $\mathrm{Tu}^{1 \dagger}$, Jingwen $\mathrm{He}^{2 \dagger}, \mathrm{Na} \mathrm{Zhou}^{3 *}$ and Xinghua Shen ${ }^{1 *}$

\begin{abstract}
Background: This study aimed to investigate the relationship between driver-passenger communicative stress and psychological distress among bus drivers, as well as whether job burnout mediates the effect of driver-passenger communicative stress on psychological distress.

Methods: A questionnaire consisting of a 12-item version of the General Health Questionnaire (GHQ-12), a oneitem driver-passenger communicative stress scale, the Maslach Burnout Inventory-General Survey (MBI-GS), as well as sociodemographic and work factors, was distributed to 310 bus drivers in Shanghai, of which 307 completed it ( $99.0 \%$ response rate). A parallel multiple mediation model with bootstrap approach, was calculated to test the mediating effect.
\end{abstract}

Results: Driver-passenger communicative stress, emotional exhaustion and cynicism were positively associated with psychological distress. Communicative stress was significantly positively linked with two of the three dimensions of burnout (emotional exhaustion and cynicism) and dependent variable. Emotional exhaustion and cynicism were positively associated with the dependent variable. The results indicate that emotional exhaustion and cynicism partially mediated the effect of communicative stress on psychological health, and that $60.0 \%$ of this effect can be explained by mediating effects, in which emotional exhaustion and cynicism weighed $63.2 \%$ and $36.8 \%$, respectively.

Conclusions: Communicative stress had effects on psychological distress among Chinese bus drivers, and job burnout was a mediator in this relationship.

Keywords: Stress, Job burnout, Mediation, Bus driver

\section{Background}

On October 28, 2018, a bus carrying 15 people suddenly lost control and plunged into the Yangtze River, from a 20-m-high bridge in Wanzhou District, Chongqing City, China. All passengers lost their lives. According to the

\footnotetext{
*Correspondence: zhounasci@sina.com; shenxhsci@sina.com

'Zhihao Tu and Jingwen He contributed equally to this work.

${ }^{3}$ Mental health education center, Facult of Psychology, The Second Military Medical University, Shanghai, China

'Department of Nautical psychology, Faculty of Psychology, The Second Military Medical University, Shanghai, China

Full list of author information is available at the end of the article
}

police investigation, a 48-year-old female passenger missed her stop and, as a consequence, first argued and then attacked the driver, causing the incident.

Previous studies on transportation safety and accident analysis, were mostly area-level or zone-level analysis, and focused mainly on macro predictors such as road network characteristics, land use patterns, and traffic information [1-4]. Fewer studies paid attention to more specific predictors, such as the ones referring to bus drivers and passengers [5].

(c) The Author(s). 2021 Open Access This article is licensed under a Creative Commons Attribution 4.0 International License, which permits use, sharing, adaptation, distribution and reproduction in any medium or format, as long as you give appropriate credit to the original author(s) and the source, provide a link to the Creative Commons licence, and indicate if changes were made. The images or other third party material in this article are included in the article's Creative Commons licence, unless indicated otherwise in a credit line to the material. If material is not included in the article's Creative Commons licence and your intended use is not permitted by statutory regulation or exceeds the permitted use, you will need to obtain permission directly from the copyright holder. To view a copy of this licence, visit http://creativecommons.org/licenses/by/4.0/. The Creative Commons Public Domain Dedication waiver (http://creativecommons.org/publicdomain/zero/1.0/) applies to the data made available in this article, unless otherwise stated in a credit line to the data. 
The seriousness of the accident mentioned above, led to a greater concern on driver-passenger communication problems, and to an increased interest and care in bus drivers' mental health.

Bus driving is a service-oriented occupation. Due to self-service buses becoming mainstream, bus drivers not only need to drive the vehicles, but also have to communicate with passengers, such as urging them to coin or swipe cards, maintaining order, answering passengers' questions and so on. Inevitably, quarrels and even fights between drivers and passengers sometimes arise during communication, which sometimes result in complaints from the passengers and administrative punishments for the drivers. However, unlike in other industries, quarrelling or fighting between passengers and drivers, may threaten the safety of everyone involved or nearby. Thus, communicating with passengers can be a big occupational source of stress for bus drivers, and long-term exposure to this stressor may have an impact on their mental health. Previous studies found that work stress was positively related to the morbidity of fatigue, anxiety, depression and other mental health problems among bus drivers [6-8]. In addition, violence from passengers can cause bus drivers to develop acute stress disorder and post-traumatic stress disorder (PTSD) [9]. Furthermore, abundant studies have demonstrated that psychological distress in professional drivers was detrimental to their capacity to safely operate vehicles [10], and thus potentially increase the risk of road accidents [11]. However, few studies have focused on the driver-passenger communicative stress, and its relationship with psychological distress among bus drivers.

Job burnout is characterized by exhaustion, cynicism, and lack of achievement and productivity at work, and it mainly occurs among people-oriented professions [12]. Among these symptoms of burnout, exhaustion and cynicism constitute the core of job burnout [13]. Exhaustion means feelings of overextension and depletion of resources, while cynicism means negative or callous responses to job responsibilities [14]. Previous studies on burnout mostly focused on medical workers, especially nurses $[15,16]$. However, as previously mentioned, drivers of self-service buses are required to deal extensively with passengers, which means they are susceptible to job burnout. Indeed, one study reported that the prevalence of severe and mild burnout was 3.6 and $30.1 \%$ respectively, among drivers and conductors in Mozambique [17]. Unfortunately, the prevalence of burnout among bus drivers in China is still not clear.

Abundant evidence showed that work stress was associated with burnout [18, 19]. According to the Job Demands-Resources (JD-R) Model, an unbalanced relationship between job demands and resources (i.e., demands outweigh resources), may cause job-related stress, which in turn can lead to job burnout and mental health issues [20]. Specifically, Hakanen et al. [21] found that the effect of job demands on health problems was mediated by job burnout (exhaustion and cynicism without professional inefficacy). Other studies also found that high demands and low resources may result in exhaustion and cynicism, but not affect professional efficacy [22, 23]. Many researchers argued that reduced professional efficacy may play a divergent role in the burnout process [13, 21, 24, 25].

Job burnout has been shown to have a wide and substantial impact on mental health, leading to an increase in alcohol consumption [26], sleep disturbance [27], and depression [28]. Yao et al. [29] found that work-related burnout was associated with the level of certain neurotransmitters in the cerebral cortex of medical workers, which may in turn cause psychological distress. Kasemy et al. [30] found that emotional exhaustion was associated with pro-inflammatory markers including IL6, TNF $\alpha$, and CoQ10. Meanwhile, inflammation is a key factor in the developmental process of mental health problems [31], including depression [32], anxiety [33] and so on. Many studies suggested that the relationship of depression and burnout is bidirectional, which means they influence each other in the manner of a vicious cycle or downward spiral [34-36]. This bidirectional relationship may also occur between burnout and sleep disturbance [37]. Zhou et al. [38] suggested that Eysenck's Psychoticism traits may moderate the relationships between burnout and anxiety mediated by coping styles. Interestingly, many studies showed that professional inefficacy dimension of burnout was also not related to health $[13,14]$. Therefore, it is reasonable to speculate that job burnout (exhaustion and cynicism without professional inefficacy) may play a mediating role between communicative stress and psychological distress among bus drivers. To the best of our knowledge, no published studies have tested this hypothesis.

It is of great significance to investigate the current situation of bus drivers' communicative stress as well as whether and how communicative stress influences drivers' mental health. From point of bus companies and the government, based on these information and knowledge, they can formulate policies accordingly and take intervention measures to alleviate drivers' communicative stress and improve their mental health. For the passengers, knowing these things will make them better understand the hardships of bus drivers and communicate with bus drivers more patiently in the future. All these mentioned above can prevent the Wanzhou tragedy from happenning again.

Thus, our study aimed to investigate 1) whether driver-passenger communicative stress was associated with psychological distress among bus drivers; and 2) 
whether job burnout mediated the effects of driverpassenger communicative stress on psychological distress. We hypothesized that 1) driver-passenger communicative stress was positively associated with psychological distress among bus drivers; and 2) two dimensions of job burnout, exhaustion and cynicism, may mediate the effects of driver-passenger communicative stress on psychological distress. Figure 1 is the hypothesized multiple mediator model.

\section{Methods}

\section{Study design and participants}

Participants $(N=310)$ were bus drivers recruited from Shanghai BA-SHI Public Transportation and the data were collected between February and March 2019. In total, 307 questionnaires were fully completed and taken for analysis, yielding a $99.0 \%$ response rate. Bus drivers were informed of voluntary participation and anonymity. All participants signed written informed consent forms following a detailed explanation about the purpose of the study. The questionnaires were delivered and collected by researchers. This study received ethical approval from the Committee on Second Military Medical University. Study conducted is in accordance with Helsinki guidelines.

\section{Measures}

\section{Sociodemographic variables}

The sociodemographic variables included age, educational level, marital status, and monthly family income (RMB). Educational level was categorized as 'secondary school', 'high school', and 'higher education'. Marital status was categorized as 'single', 'married', and 'divorced/ widowed'.

\section{Measurement of job burnout}

The Maslach Burnout Inventory - General Survey (MBIGS) was used to measure participants' burnout $[39,40]$. This survey included three subscales (emotional exhaustion, cynicism, and professional efficacy). The subscales of emotional exhaustion (5 items) and cynicism (4 items) were used in this study. All the items were scored on a Likert scale from 0 (never) to 6 (every day). The example item for the subscales of emotional exhaustion and cynicism were "I feel emotionally drained from my work", "I doubt the significance of my work" respectively. The Chinese version of the MBI-GS has been used widely in the Chinese population, and demonstrated satisfactory reliability and validity [41, 42]. In the present study, the Cronbach's $\alpha$ for emotional exhaustion and cynicism were 0.94 and 0.91 .

\section{Measurement of psychological distress}

The 12-item version of the General Health Questionnaire (GHQ-12) is a commonly accepted measure of mental health and well-being [13]. The GHQ-12 asks participants to respond to 12 items describing their health "in general over the last month". Each GHQ-12 item has 4-point responses: 'not at all $=0$ ', 'same as usual $=1$ ', 'rather more than usual $=2$ ', and 'much more than usual $=3$ ', such as "feeling nervous and strung up all the time" and "enjoying daily activities".The GHQ-12 score, obtained by summing up the scores of the 12 items, measures the severity of minor psychiatric morbidity $[43,44]$. The Chinese GHQ-12 is reliable and valid in the Chinese population $[44,45]$. In the present study, Cronbach's $\alpha$ was 0.86 .

\section{Measurement of driver-passenger communicative stress}

Until now, no measure of driver-passenger communicative stress had been used reliably. In this primary study, participants were asked to indicate their stress level on a ten-point scale, and one-item was used to measure driver-passenger communicative stress - "Please indicate the intensity of your driver-passenger communicative stress in recent month", with response anchors low $=0$, moderate $=5$, and high $=10$. This was not the first occasion where a one-item summary measure has been used.

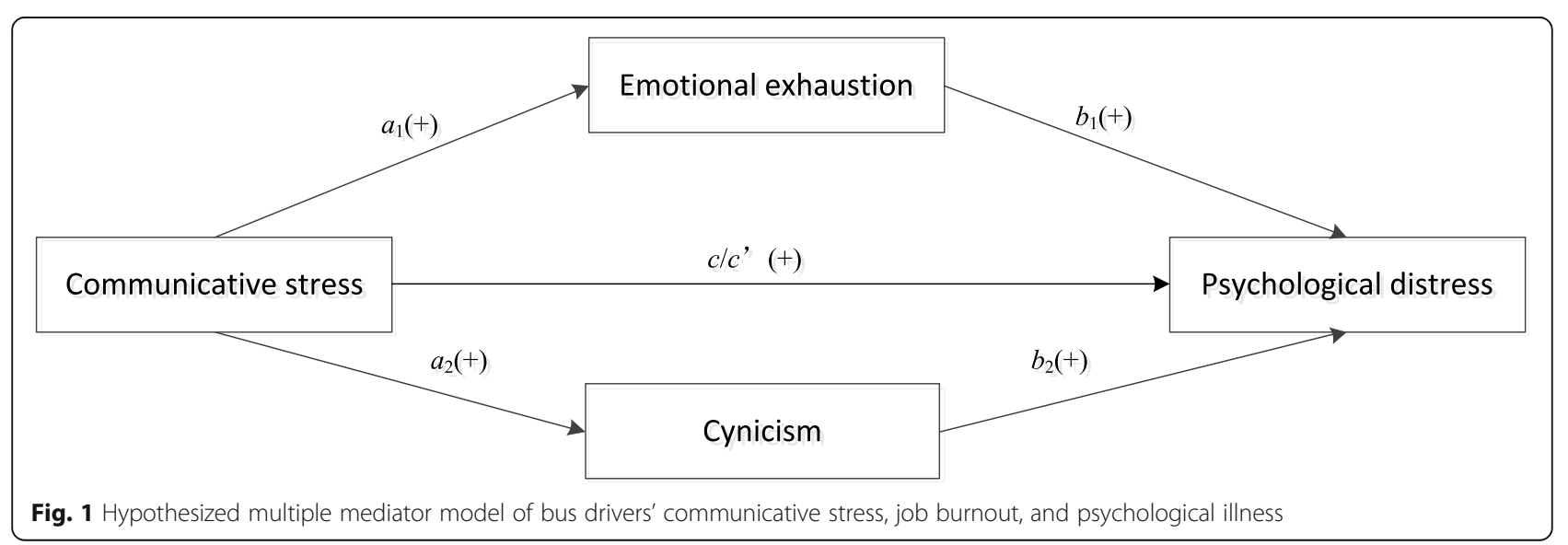


Indeed, another concept (subjective work stress) has been measured in an identical way in a previous study and it has been proven to be a valid tool [46]. Thus, it was acceptable to use this self-made scale in this study, to measure driver-passenger communicative stress.

\section{Statistical analysis}

Statistical analysis was performed with SPSS (version 22.0). Descriptive statistics such as mean, range, standard deviation, and percentages were calculated. Differences in dimensions of burnout and psychological distress among different categorical demographic groups, were tested by one-way ANOVA or independent-sample t-test. Pearson correlation was used for testing the relationship between stress, burnout and psychological distress. A parallel multiple mediation model with bootstrap approach were calculated to test the mediating effect of emotional exhaustion and cynicism, in the relationship between communicative stress and psychological disorders. We applied the procedure recommended by Hayes [47] and the PROCESS macro of SPSS [48], to test the proposed parallel multiple mediation model. Four regression equations were set to estimate the effects of communicative stress on psychological distress:

$$
\begin{aligned}
& Y=i+c X+e, \\
& M_{1}=i_{M_{1}}+a_{1} X+e_{M_{1}}, \\
& M_{2}=i_{M_{2}}+a_{2} X+e_{M_{2}},
\end{aligned}
$$

$$
\mathrm{Y}=i_{Y}+c^{\prime} X+b_{1} M_{1}+b_{2} M_{2}+e_{Y}
$$

where $Y=$ psychological distress, $X=$ communicative stress, $M_{1}=$ emotional exhaustion, $M_{2}=$ cynicism, $c=$ total effect of $X$ on $Y, c^{\prime}=$ direct effect of $X$ on $Y, a_{i}=$ effect of $X$ on $M_{i}(i=1$ to 2$), b_{i}=$ effect of $M_{i}$ on $Y(i=1$ to 2$), i$ represents intercept, and $e$ represents error.

In the present study, the PROCESS macro estimated all coefficients with ordinary least squares (OLS) regression. The particular indirect effect of $X$ on $Y$ through $M_{i}$ was represented by $a_{i} b_{i}$. The statistical significance of the specific indirect effects was tested by $95 \%$ biascorrected accelerated confidence intervals (95\% BCa CIs) on the basis of 5000 bootstrap samples. If the $95 \% \mathrm{BCa}$ CIs does not contains 0 , this particular indirect effect is considered statistically significant $[49,50]$.

\section{Results}

Demographic and working characteristics of selected bus drivers and distributions of all variables in mediating model in categorical items are shown in Table 1.

Results of Pearson correlations among variables are displayed in Table 2. Communicative stress, emotional exhaustion, cynicism, and mental illness were positively associated with each other. Both age and tenure depicted positive relationships with emotional exhaustion and cynicism. Tenure was significantly correlated with communicative stress.

The results of all the regression models set in the mediation analysis can be seen in Table 3 . The path coefficients of multiple mediator model are shown in Fig. 2 . Communicative stress was significantly positively linked with emotional exhaustion and cynicism and dependent

\begin{tabular}{|c|c|c|c|c|c|c|c|c|c|}
\hline \multirow[t]{2}{*}{ Variables } & \multirow{2}{*}{$\begin{array}{l}\text { N } \\
\text { (\%) }\end{array}$} & \multicolumn{2}{|l|}{ CS } & \multicolumn{2}{|l|}{ EE } & \multicolumn{2}{|l|}{ Cynicism } & \multicolumn{2}{|l|}{ GHQ-12 } \\
\hline & & $\begin{array}{l}\text { Mean } \\
\text { (SD) }\end{array}$ & $p$ & $\begin{array}{l}\text { Mean } \\
\text { (SD) }\end{array}$ & $p$ & $\begin{array}{l}\text { Mean } \\
\text { (SD) }\end{array}$ & $p$ & $\begin{array}{l}\text { Mean } \\
\text { (SD) }\end{array}$ & $p$ \\
\hline \multicolumn{10}{|l|}{ Sex } \\
\hline Male & $289(94.1)$ & $4.84(3.27)$ & 0.829 & $2.56(1.58)$ & 0.002 & $1.96(1.46)$ & $<0.001$ & $1.52(2.44)$ & 0.065 \\
\hline Female & $18(5.9)$ & $4.67(2.93)$ & & $1.39(0.84)$ & & $0.72(0.59)$ & & $0.44(0.78)$ & \\
\hline \multicolumn{10}{|l|}{ Education } \\
\hline Secondary school & $89(29.0)$ & $4.65(3.22)$ & 0.786 & $2.43(0.17)$ & 0.744 & $2.04(0.15)$ & 0.226 & $1.46(0.25)$ & 0.431 \\
\hline High school & $172(56.0)$ & $4.86(3.32)$ & & $2.55(0.12)$ & & $1.89(0.11)$ & & $1.56(0.18)$ & \\
\hline Undergraduate (above) & $46(15.0)$ & $5.04(3.01)$ & & $2.39(0.23)$ & & $1.59(0.21)$ & & $1.04(0.35)$ & \\
\hline \multicolumn{10}{|l|}{ Marital Status } \\
\hline Married & $260(84.7)$ & $4.85(3.15)$ & 0.653 & $2.51(1.56)$ & 0.509 & $1.93(1.44)$ & 0.170 & $1.47(2.33)$ & 0.858 \\
\hline Single & $22(7.2)$ & $4.27(3.64)$ & & $2.13(1.50)$ & & $1.33(1.22)$ & & $1.50(2.94)$ & \\
\hline Divorced/Widowed & $25(8.1)$ & $5.12(3.88)$ & & $2.61(1.84)$ & & $1.97(1.69)$ & & $1.20(2.53)$ & \\
\hline
\end{tabular}
variable. Emotional exhaustion and cynicism were

Table 1 Demographic and working characteristics of participants, and the distributions of all variables in mediating model in categorical items 
Table 2 Correlations, Means, and Standard Deviations Among Variables

\begin{tabular}{|c|c|c|c|c|c|c|c|c|c|}
\hline Variable & $M$ & SD & 1 & 2 & 3 & 4 & 5 & 6 & 7 \\
\hline 1. CS & 4.83 & 3.24 & 1 & & & & & & \\
\hline 2. $\mathrm{EE}$ & 2.49 & 1.57 & $0.67^{* * *}$ & 1 & & & & & \\
\hline 3. cynicism & 1.89 & 1.45 & $0.47^{* * *}$ & $0.79^{* * *}$ & 1 & & & & \\
\hline 4. GHQ-12 & 1.45 & 2.38 & $0.42^{* * *}$ & $0.51^{* * *}$ & $0.47^{* * *}$ & 1 & & & \\
\hline 5. Age & 45.60 & 8.53 & 0.10 & $0.15^{* *}$ & $0.21^{* * * *}$ & 0.11 & 1 & & \\
\hline 6. Tenure & 20.92 & 11.60 & $0.15^{*}$ & $0.16^{* *}$ & $0.18^{* *}$ & 0.09 & $0.78^{* * *}$ & 1 & \\
\hline 7. Income & 8187.32 & 2438.76 & -0.10 & -0.06 & -0.02 & -0.07 & 0.14 & 0.00 & 1 \\
\hline
\end{tabular}

Note: $N=307 . \mathrm{CS}=$ communicative stress, $\mathrm{EE}=$ emotional exhaustion, GHQ-12 $=12$-item Chinese version of the General Health Questionnaire

a ${ }^{*} p<.05 .{ }^{* *} p<.01 .{ }^{* * *} p<.001$

positively associated with the dependent variable. The results indicate that emotional exhaustion and cynicism partially mediated the effect of communicative stress on psychological health, and that $61.3 \%$ of this effect can be explained by mediating effects, in which emotional exhaustion and cynicism weighed 63.2 and $36.8 \%$, respectively. The total, direct and indirect effects are all presented in Table 4.

\section{Discussion}

To the best of our knowledge, this was the first study examining the relationship between stress and mental health among bus drivers, as well as investigating the mediating effect of job burnout between the two.

\section{Direct effect of communicative stress on mental health}

More precisely, we found that driver-passenger communicative stress was positively associated with psychological distress. This study also demonstrated that emotional exhaustion and cynicism partially mediated the effect of driver-passenger communicative stress on mental illness. These findings were as expected, and in line with previous studies. For example, Useche et al. [11] found that overall work-related stress was associated with mental health issues among professional drivers. Another study investigated the relationship between nine major types of work stressors (driver-passenger communicative stress was not included) and biomarkers of stress, 24-h urine cortisol and serum dehydroepiandrosterone-sulfate (DHEA-S), among bus drivers in Taiwan [51]. The results showed that only "poor relationship with supervisor" and "imbalanced salary and bonus" were significantly associated with biomarkers of stress. Although previous studies have neglected the effect of driverpassenger communicative stress on psychological distress, the results of our study showed that communicating with passengers is a big work-related stressor for bus drivers, and can indeed influence their mental health.

Indirect effect of communicative stress on mental health As mentioned above, our results also show that emotional exhaustion and cynicism partially mediate the effect of driver-passenger communicative stress on psychological health. Indeed, bus drivers who experience a higher level of communicative stress are more likely to show symptoms of exhaustion and cynicism, which in turn can affect their mental health. In this process, reduced professional efficacy did not seem to play an important role. The findings were as expected and agreed with previous studies. For example, Chen et al. [52] studied 1029 young nurses, and found that job burnout had a mediating effect in the relationship between job stress and mental health.

Table 3 Regression coefficients, standard errors, and model summary information for the presumed parallel multiple mediator model

\begin{tabular}{|c|c|c|c|c|c|c|c|c|c|c|c|c|}
\hline \multirow[t]{2}{*}{ Antecedent } & & \multicolumn{2}{|l|}{$Y$} & & \multicolumn{2}{|l|}{$M_{1}$} & & \multicolumn{2}{|l|}{$M_{2}$} & & \multicolumn{2}{|l|}{$Y$} \\
\hline & & $\bar{\beta}$ & $p$ & & $\bar{\beta}$ & $p$ & & $\beta$ & $p$ & & $\beta$ & $p$ \\
\hline$x$ & \multirow[t]{3}{*}{ c } & 0.307 & $<0.001$ & $a_{1}$ & 0.327 & $<0.001$ & $a_{2}$ & 0.209 & $<0.001$ & $c^{\prime}$ & 0.120 & 0.015 \\
\hline$M_{1}$ & & & & & & & & & & $b_{1}$ & 0.359 & 0.013 \\
\hline$M_{2}$ & & & & & & & & & & $b_{2}$ & 0.333 & 0.011 \\
\hline Constant & \multirow[t]{2}{*}{ i } & -0.029 & 0.897 & $i_{M_{1}}$ & 0.912 & $<0.001$ & $i_{M_{2}}$ & 0.879 & $<0.001$ & $i_{Y}$ & -0.648 & 0.005 \\
\hline Model Fit & & \multicolumn{3}{|c|}{$\begin{array}{l}R^{2}=0.174 \\
p<0.001\end{array}$} & \multicolumn{2}{|c|}{$\begin{array}{l}R^{2}=0.454 \\
p<0.001\end{array}$} & & \multicolumn{2}{|c|}{$\begin{array}{l}R^{2}=0.218 \\
p<0.001\end{array}$} & & \multicolumn{2}{|c|}{$\begin{array}{l}R^{2}=0.282 \\
p<0.001\end{array}$} \\
\hline
\end{tabular}




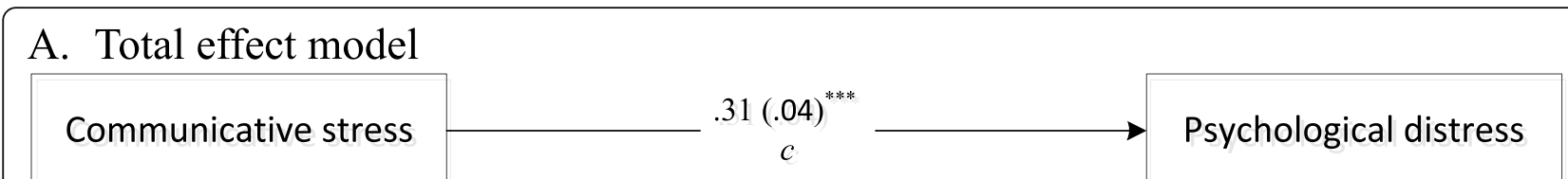

\section{B. Multiple mediator model}

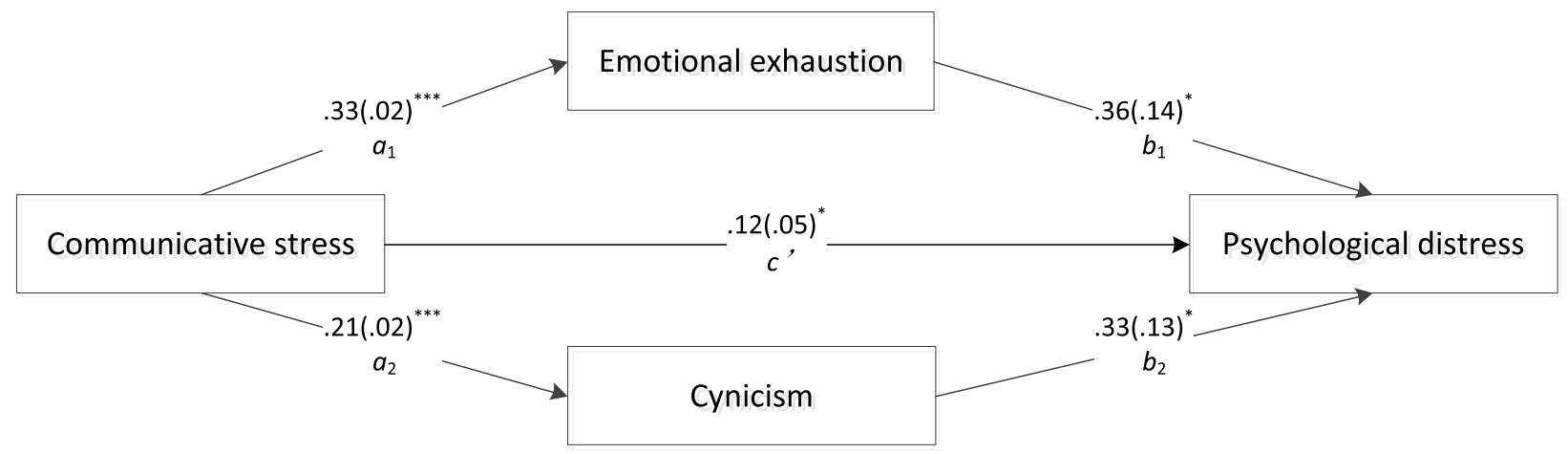

Fig. 2 Multiple mediation with psychological illness as criterion. Path coefficients correspond to unstandardized parameter estimates (standard errors in parentheses). ${ }^{*} p<.05 .{ }^{* *} p<.01 .{ }^{* * *} p<.001$

\section{Effect of communicative stress on burnout}

Maslach et al. [24] provided a sophisticated theoretical framework to understand job burnout in their influential review article. This framework identifies six kinds of mismatch contributing to job burnout: context, workload, control, reward, community, fairness, and values. In the present study, the path from communicative stress to job burnout may be attributed to the mismatch of fairness. In fact, bus drivers can be described as a vulnerable group, when they get involved in a dispute with passengers. As a matter of fact, even when it is the passenger who is unpleasant and impolite, as soon as the bus company receives the complaint from the passenger, the incident will be recorded and the driver will be warned and/or punished. Furthermore, on some occasions, drivers are forced to endure violence from passengers while driving, as to not risk a serious road accident.

Table 4 Total, total indirect, specific indirect, and direct effects of the multiple mediator model

\begin{tabular}{llll}
\hline & Estimate & S.E. & {$[95 \% \mathrm{Cl}]$} \\
\hline Total effect & 0.31 & 0.04 & {$[0.23,0.38]$} \\
Total indirect effect & 0.19 & 0.04 & {$[0.11,0.27]$} \\
Direct effect & 0.12 & 0.05 & {$[0.02,0.22]$} \\
Specific indirect effect & & & \\
Emotional exhaustion & 0.12 & 0.05 & {$[0.02,0.21]$} \\
Cynicism & 0.07 & 0.03 & {$[0.01,0.14]$} \\
\hline
\end{tabular}

Note: $S E$ standard error, $\mathrm{Cl}$ confidence intervals
Thus, a feeling of unfairness may ensue within driverpassenger communication. Maslach et al. [24] suggested that a lack of fairness may aggravate burnout in at least two ways. First, both personal and colleagues' experiences of unfair treatment can be emotionally exhausting. Second, unfairness may raise a deep sense of cynicism related to the job [24]. From the view of JD-R model, dealing with passengers while driving can carry a high emotional demand and overall workload. Unfortunately, there are not enough job resources for bus drivers on the road, to cope with the high job demands. This unbalanced relationship between job demands and resources can result in stress and burnout.

\section{Effect of burnout on mental health}

The effect pathway from burnout to psychological distress has been extensively studied, and many variables seem to play a mediating role in this., for example, resilience and emotional regulation [52, 53]. In addition, DNA methylation may also be involved in this process [18]. It is worth noting that many researchers have argued the occurrence of an extensive overlap between burnout and depression [54, 55]. Indeed, Orosz et al. [56] found that burnout cannot be distinguished from depression from biological indicators (brain-derived neurotrophic factor (BDNF), heart rate variability (HRV), and hippocampal volume). However, other researchers believe that the apparent overlap between burnout and depression is, instead, a result of different definitions of 
burnout [54]. A longitudinal study showed that burnout (exhaustion and cynicism) was a precursor of mental illness [13]. Thus, the issue of burnoutdepression overlap needs more in-depth studies in the future [54].

\section{Limitations}

Several limitations of the present study must also be addressed. First, this was a cross-sectional study, which cannot evaluate the temporality and causality. Even though we used mediation analysis, the causal relationships among job burnout, communicative stress, and psychological disorder, cannot be determined in the present study. Second, stress, job burnout and psychological distress were all measured by self-reported questionnaires, and the results may be affected by response bias. Third, despite the extensive level of adjustment in our study, the possibility remains that unmeasured confounders such as coping style, personality and physical health could explain part of the association between stress and psychological distress [57, 58]. Thus, the mediating effect of burnout (61.3\% in this study) may be over rated. Lastly, fourth, we used only one item to measure driver-passenger communicative stress, which might not be very reliable. In addition, the item actually measures driver-passenger communicative stress in recent month. However, Metzenthin et al. [46] argued that one-item subjective work stress assessment tool was more accurate measuring contemporaneously than retrospectively.

\section{Implications for research and practice}

Driver-passenger communication problem is a major threat to traffic safety, but it is always neglected by scholars and administration. To our best knowledge, this research was the first study focusing on the negative effect of driver-passenger communicative stress on mental health of bus drivers. From acedemic point of view, we suggest that, first, future researchers should develop a psychometrically sound measurement of driverpassenger communicative stress. Second, future researchers should design additional longitudinal studies to determine whether or not the causal relationships among job burnout, communicative stress, and mental illness exist. Third, this study showed that Chinese bus drivers are susceptible to burnout and suffer mental health problems. Thus, more studies should be conducted focunsing on bus drivers' well-being. From practical point of view, the government and bus companies should take actions to protect bus drivers. The present study showed that driver-passenger communicative stress is harmful to drivers' mental health and job burnout plays an important role in this process. Driverpassenger communicative stress mainly comes from the driver's weak position relative to passengers. The favoritism of passengers by the government and bus companies makes matters worse and further leads to feeling of unfairness and burnout among drivers. Thus, the protection of bus drivers and penalties for irrational passengers should be strengthened both legislatively and administratively, which can relieve communicative stress at the source. In addition, this move can improve drivers' sense of fairness and reduce job burnout, which can in turn enhance their mental health.

\section{Conclusions}

The present study found that driver-passenger communicative stress had negative effects on job burnout and psychological disorders among Chinese bus drivers. Meanwhile, psychological disorders are associated with burnout. According to the result of mediation analysis, job burnout has a positive mediating effect on the path from driver-passenger communicative stress to psychological disorders. This result means that the more driver-passenger communicative stress bus drivers put up with, the higher level of burnout they suffer, which in turn leads to more symptoms of psychological disorders. The mediating effect of burnout can explain $60 \%$ of the total effect.

\section{Abbreviations \\ GHQ-12: The General Health Questionnaire; MBI-GS: The Maslach Burnout Inventory-General Survey; PTSD: Post-traumatic stress disorder; JD-R: the Job Demands-Resources; OLS: Ordinary least squares; BC: Bias-corrected; $\mathrm{Cl}$ : Confidence intervals; CS: Communicative stress; EE: Emotional exhaustion; PE: Professional efficacy; SE: Standard error; DHEA-S: Serum dehydroepiandrosterone-sulfate; BDNF: Brain-derived neurotrophic factor; HRV: Heart rate variability}

\section{Acknowledgements}

We would like to thank Editage (www.editage.cn) for English language editing.

\section{Authors' contributions}

Conceptualization, N.Z., X.S.; methodology, Z.T., J.H.; data collection, N.Z.; writing-original draft preparation, Z.T., J.H.; writing--review and editing, N.Z., X.S.; supervision, N.Z., X.S. All authors have read and agreed to the published version of the manuscript. The author(s) read and approved the final manuscript.

\section{Funding}

This study was supported by the Shanghai municipal health commission (CN) (201940093).

\section{Availability of data and materials}

All data generated or analysed during this study are available from the corresponding author on reasonable request.

\section{Declarations}

Ethics approval and consent to participate

Study participants completed a written informed consent. The study procedures were approved by the Ethics Comittee of the Second Military Medical University. Human rights and ethics issues were taken into consideration when the survey was designed. Study conducted is in accordance with Helsinki guidelines. Written consent was obtained from each participant following a detail explanation about the purpose of the 
study. Participation in the study was voluntary and anonymous, and participants' information was kept completely condential.

\section{Competing interests}

The authors declare that they have no competing interests.

\section{Author details}

${ }^{1}$ Department of Nautical psychology, Faculty of Psychology, The Second Military Medical University, Shanghai, China. ${ }^{2}$ Department of Medical Psychology, NO.96609 Hospital, Yinchuan, China. ${ }^{3}$ Mental health education center, Facult of Psychology, The Second Military Medical University, Shanghai, China.

\section{Received: 19 January 2021 Accepted: 10 March 2021}

\section{Published online: 20 March 2021}

\section{References}

1. Huang H, Song B, Xu P, Zeng Q, Lee J, Abdel-Aty M. Macro and micro models for zonal crash prediction with application in hot zones identification. J Transp Geogr. 2016;54:248-56. https://doi.org/10.1016/j.jtra ngeo.2016.06.012.

2. Zeng Q, Guo Q, Wong SC, Wen H, Huang H, Pei X. Jointly modeling arealevel crash rates by severity: a Bayesian multivariate random-parameters spatio-temporal Tobit regression. Transp A. 2019;15(2):1867-84. https://doi. org/10.1080/23249935.2019.1652867.

3. Zeng Q, Wen $\mathrm{H}$, Huang $\mathrm{H}$, Pei X, Wong SC. A multivariate randomparameters Tobit model for analyzing highway crash rates by injury severity. Accid Anal Prev. 2017;99(Pt A):184-91. https://doi.org/10.1016/j.aap.2016.11.018.

4. Zeng Q, Wen H, Wong SC, Huang H, Guo Q, Pei X. Spatial joint analysis for zonal daytime and nighttime crash frequencies using a Bayesian bivariate conditional autoregressive model. J Transp Saf Secur. 2020;12(4):566-85. https://doi.org/10.1080/19439962.2018.1516259.

5. Af Wåhlberg AE. Long-term prediction of traffic accident record from bus driver celeration behavior. Int J Occup Saf Ergon. 2007;13(2):159-71. https:// doi.org/10.1080/10803548.2007.11076717.

6. Useche SA, Ortiz VG, Cendales BE. Stress-related psychosocial factors at work, fatigue, and risky driving behavior in bus rapid transport (BRT) drivers. Accid Anal Prev. 2017;104:106-14. https://doi.org/10.1016/j.aap.2017.04.023.

7. Tse JLM, Flin R, Mearns K. Bus driver well-being review: 50 years of research. Transp Res Part F Traffic Psychol Behav. 2006;9(2):89-114. https://doi.org/1 0.1016/j.trf.2005.10.002.

8. Gómez-Ortiz V, Cendales B, Useche S, Bocarejo JP. Relationships of working conditions, health problems and vehicle accidents in bus rapid transit (BRT) drivers. Am J Ind Med. 2018;61(4):336-43. https://doi.org/10.1002/ajim.22821.

9. Zhou B, Boyer R, Guay S. Dangers on the road: a longitudinal examination of passenger-initiated violence against bus drivers. Stress Health. 2018;34(2): 253-65. https://doi.org/10.1002/smi.2779.

10. Alavi SS, Mohammadi MR, Souri H, Mohammadi Kalhori S, Jannatifard F, Sepahbodi G. Personality, driving behavior and mental disorders factors as predictors of road traffic accidents based on logistic regression. Iran J Med Sci. 2017;42(1):24-31

11. Useche SA, Cendales B, Montoro L, Esteban C. Work stress and health problems of professional drivers: a hazardous formula for their safety outcomes. Peer J. 2018;2018(12):1-24. https://doi.org/10.7717/peerj.6249.

12. Maslach C. What have we learned about burnout and health? Psychol Health. 2001;16(5):607-11. https://doi.org/10.1080/08870440108405530.

13. Huang CS, Simha A. The mediating role of burnout in the relationships between perceived fit, leader-member exchange, psychological illness, and job performance. Int J Stress Manag. 2018;25(S1):26-42. https://doi.org/10.1 037/str0000077.

14. Gan Y, Jiang H, Li L, Yang Y, Wang C, Liu J, Yang T, Opoku S, Hu S, Xu H, Herath C, Chang Y, Fang P, Lu Z. Prevalence of burnout and associated factors among general practitioners in Hubei, China: a cross-sectional study. BMC Public Health. 2019;19(1):1607. https://doi.org/10.1186/s12889-019-7755-4.

15. Zhang L-F, You L-M, Liu K, Zheng J, Fang J-B, Lu M-M, Lv AL, Ma WG, Wang J, Wang SH, Wu X, Zhu XW, Bu XQ. The association of Chinese hospital work environment with nurse burnout, job satisfaction, and intention to leave. Nurs Outlook. 2014;62(2):128-37. https://doi.org/10.1016/j.outlook.2013.10.010.

16. Martinelli N, Frattolillo M, Sansone V. High prevalence of burnout syndrome in orthopedic nurses in Italy. Int J Orthop Trauma Nurs. 2020;37:100747. https://doi.org/10.1016/j.ijotn.2019.100747.
17. Couto MT, Lawoko S. Burnout, workplace violence and social support among drivers and conductors in the road passenger transport sector in Maputo city, Mozambique. J Occup Health 2011;53(3): 214-221. doi:10.1539/joh. L10102.

18. Bakusic J, Schaufeli W, Claes S, Godderis L. Stress, burnout and depression: a systematic review on DNA methylation mechanisms. J Psychosom Res. 2017;92:34-44. https://doi.org/10.1016/j.jpsychores.2016.11.005.

19. Van Der Wal RAB, Wallage J, Bucx MJL. Occupational stress, burnout and personality in anesthesiologists. Curr Opin Anaesthesiol. 2018;31(3):351-6. https://doi.org/10.1097/ACO.0000000000000587.

20. Bakker $A B$, Demerouti $E$. The job demands-resources model: state of the art J Manag Psychol. 2007;22(3):309-28. https://doi.org/10.1108/0268394071 0733115.

21. Hakanen JJ, Bakker AB, Schaufeli WB. Burnout and work engagement among teachers. J Sch Psychol. 2006;43(6):495-513. https://doi.org/10.1016/j. jsp.2005.11.001.

22. Bakker $A B$, Demerouti $E$, Euwema $M C$. Job resources buffer the impact of job demands on burnout. J Occup Health Psychol. 2005;10(2):170-80. https://doi.org/10.1037/1076-8998.10.2.170.

23. Xanthopoulou D, Bakker AB, Demerouti E, Schaufeli WB. The role of personal resources in the job demands-resources model. Int J Stress Manag. 2007:14(2):121-41. https://doi.org/10.1037/1072-5245.14.2.121.

24. Maslach C, Schaufeli WB, Leiter MP. Job burnout. Annu Rev Psychol. 2001; 52(1):397-422. https://doi.org/10.1146/annurev.psych.52.1.397.

25. Virga D, Baciu EL, Lazar TA, Lupsa D. Psychological capital protects social workers from burnout and secondary traumatic stress. Sustainability. 2020; 12(6):2246. https://doi.org/10.3390/su12062246.

26. Ahola K, Honkonen T, Pirkola S, Isometsä E, Kalimo R, Nykyri E, Aromaa A, Lönnqvist J. Alcohol dependence in relation to burnout among the Finnish working population. Addiction. 2006;101(10):1438-43. https://doi.org/1 0.1111/j.1360-0443.2006.01539.x.

27. Kim H, Ji J, Kao D. Burnout and physical health among social workers: a three-year longitudinal study. Soc Work. 2011;56(3):258-68. https://doi.org/1 0.1093/sw/56.3.258.

28. Armon G, Melamed S, Toker S, Berliner S, Shapira I. Joint effect of chronic medical illness and burnout on depressive symptoms among employed adults. Health Psychol. 2014;33(3):264-72. https://doi.org/10.1037/a0033712.

29. Yao Y, Zhao S, Zhang Y, Tang L, An Z, Lu L, Yao S. Job-related burnout is associated with brain neurotransmitter levels in Chinese medical workers: a cross-sectional study. J Int Med Res. 2018;46(8):3226-35. https://doi.org/1 $0.1177 / 0300060518775003$.

30. Kasemy ZA, Abd-Ellatif EE, Abdel Latif AA, Bahgat NM, Shereda HMA, Shattla SI, Aboalizm SE, Abd Elhy AH, Allam AR, Ramadan AN, Amer HM, Ahmed NA, AlJifri AA, el Dalatony MM. Prevalence of Workaholism among Egyptian healthcare workers with assessment of its relation to quality of life, mental health and burnout. Front Public Health. 2020;8:581373. https://doi.org/10.33 89/fpubh.2020.581373.

31. Carpenter LL, Gawuga CE, Tyrka AR, Lee JK, Anderson GM, Price LH. Association between plasma IL-6 response to acute stress and early-life adversity in healthy adults. Neuropsychopharmacology. 2010;35(13):2617-23. https://doi.org/10.1038/npp.2010.159.

32. Dantzer R, O'Connor JC, Freund GG, Johnson RW, Kelley KW. From inflammation to sickness and depression: when the immune system subjugates the brain. Nat Rev Neurosci. 2008;9(1):46-56. https://doi.org/10.1 038/nrn2297.

33. Vogelzangs N, Beekman AT, de Jonge P, Penninx BW. Anxiety disorders and inflammation in a large adult cohort. Transl Psychiatry. 2013;3(4):e249. https://doi.org/10.1038/tp.2013.27.

34. Toker S, Biron M. Job burnout and depression: unraveling their temporal relationship and considering the role of physical activity. J Appl Psychol. 2012;97(3):699-710. https://doi.org/10.1037/a0026914.

35. Huibers MJ, Leone SS, van Amelsvoort LG, Kant I, Knottnerus JA. Associations of fatigue and depression among fatigued employees over time: a 4-year follow-up study. J Psychosom Res. 2007;63(2):137-42. https:// doi.org/10.1016/j.jpsychores.2007.02.014.

36. Skapinakis $P$, Lewis $G$, Mavreas $V$. Temporal relations between unexplained fatigue and depression: longitudinal data from an international study in primary care. Psychosom Med. 2004;66(3):330-5. https://doi.org/10.1097/01. psy.0000124757.10167.b1.

37. Pagnin D, de Queiroz V, Carvalho YT, Dutra AS, Amaral MB, Queiroz TT. The relation between burnout and sleep disorders in medical students. Acad Psychiatry. 2014;38:438-44. https://doi.org/10.1007/s40596-014-0093-z. 
38. Zhou J, Yang Y, Qiu X, Yang X, Pan H, Ban B, Qiao Z, Wang L, Wang W. Relationship between anxiety and burnout among Chinese physicians: a moderated mediation model. PLoS One. 2016;11(8):e0157013. https://doi. org/10.1371/journal.pone.0157013.

39. Schaufeli WB, Taris TW. The conceptualization and measurement of burnout: common ground and worlds apart. Work Stress. 2005;19(3):256-62. https:// doi.org/10.1080/02678370500385913.

40. Kalimo R, Pahkin K, Mutanen P, Toppinen-Tanner S. Staying well or burning out at work: work characteristics and personal resources as long-term predictors. Work Stress. 2003;17(2):109-22. https://doi.org/10.1080/026783 7031000149919

41. Wen J, Cheng Y, Hu X, Yuan P, Hao T, Shi Y. Workload, burnout, and medical mistakes among physicians in China: a cross-sectional study. Biosci Trends. 2016;10(1):27-33. https://doi.org/10.5582/bst.2015.01175.

42. Wang Y, Chang Y, Fu J, Wang L. Work-family conflict and burnout among Chinese female nurses: the mediating effect of psychological capital. BMC Public Health. 2012;12(1):915. https://doi.org/10.1186/1471-2458-12-915.

43. Pevalin DJ. Multiple applications of the GHQ-12 in a general population sample: An investigation of long-term retest effects. Soc Psychiatry Psychiatr Epidemiol. 2000;35(11):508-12. https://doi.org/10.1007/s001270050272.

44. Zhong BL, Liu TB, Chan SSM, Jin D, Hu CY, Dai J, Chiu HFK. Common mental health problems in rural-to-urban migrant workers in Shenzhen, China: prevalence and risk factors. Epidemiol Psychiatr Sci. 2018;27(3):256-65. https://doi.org/10.1017/\$2045796016001141.

45. Guan M, Han B. Factor structures of general health questionnaire-12 within the number of kins among the rural residents in China. Front Psychol. 2019; 10. https://doi.org/10.3389/fpsyg.2019.01774.

46. Metzenthin P, Helfricht S, Loerbroks A, Terris DD, Haug HJ, Subramanian SV, Fischer JE. A one-item subjective work stress assessment tool is associated with cortisol secretion levels in critical care nurses. Prev Med. 2009;48(5): 462-6. https://doi.org/10.1016/j.ypmed.2009.02.001.

47. Hayes AF. Introduction to mediation, moderation, and conditional process analysis: a regression-based approach. 2nd ed. New York, NY: The Guilford Press; 2018. p. 147-86.

48. Hayes AF. PROCESS: a versatile computational tool for observed variable mediation, moderation, and conditional process modeling [White Paper]. 2012. Available form http://www.afhayes.com/public/process2012.pdf

49. Preacher KJ, Hayes AF. Asymptotic and resampling strategies for assessing and comparing indirect effects in multiple mediator models. Behav Res Methods. 2008;40(3):879-91. https://doi.org/10.3758/BRM.40.3.879.

50. Preacher KJ, Rucker DD, Hayes AF. Addressing moderated mediation hypotheses: theory, methods, and prescriptions. Multivariate Behav Res. 2007;42(1):185-227. https://doi.org/10.1080/00273170701341316.

51. Du CL, Lin MC, Lu L, Tai JJ. Correlation of occupational stress index with 24 hour urine cortisol and serum DHEA sulfate among city bus drivers: a crosssectional study. Saf Health Work. 2011;2(2):169-75. https://doi.org/10.5491/ SHAW.2011.2.2.169.

52. Chen J, Li J, Cao B, Wang F, Luo L, Xu J. Mediating effects of self-efficacy, coping, burnout, and social support between job stress and mental health among young Chinese nurses. J Adv Nurs. 2020;76(1):163-73. https://doi. org/10.1111/jan.14208.

53. Akbari M, Hossaini SM. The relationship of spiritual health with quality of life, mental health, and burnout: the mediating role of emotional regulation. Iran J Psychiatry. 2018;13(1):22-31.

54. Bianchi R, Schonfeld IS, Laurent E. Biological research on burnoutdepression overlap: long-standing limitations and on-going reflections. Neurosci Biobehav Rev. 2017;83:238-9. https://doi.org/10.1016/j.neubiorev.2 017.10.019.

55. Bianchi R, Schonfeld IS, Laurent E. Burnout-depression overlap: a review. Clin Psychol Rev. 2015;36:28-41. https://doi.org/10.1016/j.cpr.2015.01.004.

56. Orosz A, Federspiel A, Haisch S, Seeher C, Dierks T, Cattapan K. A biological perspective on differences and similarities between burnout and depression. Neurosci Biobehav Rev. 2017;73:112-22. https://doi.org/10.1016/ j.neubiorev.2016.12.005.

57. Pourabdian S, Lotfi S, Yazdanirad S, Golshiri P, Hassanzadeh A. Evaluation of the effect of fatigue on the coping behavior of international truck drivers. BMC Psychol. 2020;8:70. https://doi.org/10.1186/s40359-020-00440-2.
58. Hege A, Lemke MK, Apostolopoulos Y, Sönmez S. The impact of work organization, job stress, and sleep on the health Behaviors and outcomes of U.S. long-haul truck drivers. Health Educ Behav. 2019;46(4):626-36. https:// doi.org/10.1177/1090198119826232.

\section{Publisher's Note}

Springer Nature remains neutral with regard to jurisdictional claims in published maps and institutional affiliations.

\section{Ready to submit your research? Choose BMC and benefit from:}

- fast, convenient online submission

- thorough peer review by experienced researchers in your field

- rapid publication on acceptance

- support for research data, including large and complex data types

- gold Open Access which fosters wider collaboration and increased citations

- maximum visibility for your research: over $100 \mathrm{M}$ website views per year

At $\mathrm{BMC}$, research is always in progress.

Learn more biomedcentral.com/submissions 